\title{
PTCH2 wt Allele
}

National Cancer Institute

\section{Source}

National Cancer Institute. PTCH2 wt Allele. NCI Thesaurus. Code C51296.

Human PTCH2 wild-type allele is located within 1p33-p34 and is approximately $21 \mathrm{~kb}$ in length. This allele, which encodes protein patched homolog 2 protein, is involved in the formation of embryonic structures. Aberrant allelic expression has been linked to medulloblastoma and basal cell carcinoma, suggesting that variants play a role in the development of some tumors. 